\title{
PHYSICAL ACTIVITY REGULATES THE INTESTINAL MICROBIOTA COMPOSITION
}

\author{
Mihaela JURDANA $^{1} \&$ Darja BARLIČ-MAGANJA ${ }^{1}$ \\ ${ }^{1}$ University of Primorska, Faculty of Health Sciences, Slovenia \\ Corresponding Author: \\ Mihaela JURDANA \\ University of Primorska, Faculty of Health Sciences, Polje 42, Izola, Slovenia \\ Phone: +38656626469 \\ E-mail: mihaela.jurdana@fvz.upr.si
}

\begin{abstract}
Gut microbiota is the name given today to the bacterial population living in our intestine. It provides nutrients, metabolites and affects the immune system. Recent animals and human studies suggest that regular physical activity increases the presence of beneficial microbial species of gut microbiota and improves the health status of the host. When gut bacteria diversity reduces, there are systemic consequences leading to gastrointestinal, physiological and psychological distress. This review describes the communication pathway of the microbiota-gut-brain axes and other possible mechanisms by which physical activity causes changes in microbiota composition. Furthermore, it provides the latest evidence of the beneficial role of exercise, which in turn can affect health and various disease processes. The results of research studies in this area are increasingly becoming a focus of scientific attention.
\end{abstract}

Keywords: Gut microbiota, physical exercise, health. 
Mihaela JURDANA, Darja BARLIČ-MAGANJA: PHYSICAL ACTIVITY REGULATES THE INTESTINAL MICROBIOTA COMPOSITION, 99-114

\section{TELESNA AKTIVNOST URAVNAVA SESTAVO ČREVESNE MIKROBIOTE}

\section{IZVLE ¿̌EK}

Črevesna mikrobiota je bakterijska združba v črevesju. Zagotavlja hranila, metabolite in vpliva na imunski sistem. Nedavne študije na živalih in ljudeh nakazujejo, da redna telesna aktivnost povečuje prisotnost koristnih bakterijskih vrst, ki so del črevesne mikrobiote in na ta način izboljšuje zdravstveno stanje gostitelja. Upad raznolikosti črevesnih bakterij vodi v sistemske posledice, ki povzročajo gastrointestinalne, fiziološke in psihološke težave. Pregledni članek opisuje komunikacijsko pot, os mikrobiota-črevesje-možgani ter druge možne mehanizme, s katerimi telesna aktivnost povzroča spremembe v sestavi mikrobiote. Poleg tega ponuja najnovejše dokaze o koristni vlogi telesne aktivnosti, kar lahko vpliva na zdravje in različne bolezenske procese. Rezultati raziskav na tem področju so vse bolj v središču pozornosti znanstvenikov.

Ključne besede: črevesna mikrobiota, telesna aktivnost, zdravje. 
Mihaela JURDANA, Darja BARLIČ-MAGANJA: PHYSICAL ACTIVITY REGULATES THE INTESTINAL MICROBIOTA COMPOSITION, 99-114

\section{INTRODUCTION}

\section{Microbiota in Gastrointestinal Tract}

The human gastrointestinal tract (GIT) is inhabited by trillions of microbial cells whose coordinated actions are important in human life, having crucial roles in several physiological and pathological processes (Clemente, Ursell, Parfrey \& Knight, 2012). These microorganisms are known as gut microbiota and are sometimes referred to as a »forgotten organ" (O’Hara \& Shanahan, 2006). The gut microbiota is mostly made up of two bacterial phyla. More than $90 \%$ of them belong to Bacteroidetes and Firmicutes, including species of Ruminococcus, Lactobacillus and Clostridium genera, whereas the minority of species belong to phyla such as Actinobacteria and Proteobacteria. Firmicutes phyla mainly includes Ruminococcus, Clostridium, Lactobacillus, Eubacterium, Faecalibacterium and Roseburia, while in Bacteroides mainly Prevotella and Xylanibacter are represented (Eckburg et al., 2005).

The number, type and function of microbiota along the entire GIT have a great variability. Its density and diversity increase steadily along the GIT. The highest concentration is reached in large bowel where a complex group of microorganisms ferment different non-digestable food components (Bäckhed, Ley, Sonnenburg, Peterson \& Gordon, 2005). The gut microbiota functions are highly preserved between individuals, whereas each individual's gut microbiota is characterized by a specific combination of bacterial species due to inter-individual and intra-individual variations throughout human life. Its composition is influenced by different factors like microbial species acquired at birth, host genetics, immunological factors, drugs like antibiotics and nutrition (Bokulich et al., 2016; Yatsunenko et al., 2012; Kashtanova, Popenko, Tkacheva, Tyakht, Alexeev \& Boytsov, 2016). Recent studies indicated that physical activity is also one of the main positive modulators of gut microbiota biodiversity. Beneficial effects of exercise on gut microbiota has been supported by investigations performed in animals and confirmed in human studies (Ticinesi, Lauretani, Tana, Nouvenne, Ridolo \& Meschi, 2019).

The development and maturation of gut microbiota start in early life. Colonization of the infant gut should begin already during the antenatal period before the delivery (Aagaard, Ma, Antony, Ganu, Petrosino \& Versalovic, 2014). After the birth, the infant gut is exposed to complex surrounding environmental and maternal microbiota which begins to colonize the GIT. The development and maturation of gut microbiota are influenced by several intrinsic and extrinsic factors, like mode of delivery, mother's age, diet and metabolic status, type of feeding, family genetics and lifestyle (Rodriguez et al., 2015; Milani et al., 2017). The introduction of solid food to an infant diet changes the microbiota and by the age of three it resembles a relatively stable adult-like profile with a dense microbial population (Milani et al., 2017). In general, changes occur in the elderly population showing a significant decrease in bacterial diversity, especially a decrease in Bacteroidetes and an increase in Firmicutes (Claesson et al., 2012). Although these may be related to physiological alterations there is now evidence that diet 
Mihaela JURDANA, Darja BARLIČ-MAGANJA: PHYSICAL ACTIVITY REGULATES THE INTESTINAL MICROBIOTA COMPOSITION, 99-114

also plays an important role. Dietary factors, particularly carbohydrate and protein intake, are generally considered as the main determinants of gut microbiota composition (Milani et al., 2016).

The preservation of a normal and healthy gut microbiota plays a critical role in maintaining good health, with possible effects on the motility of GIT, conversion of food into useful nutrients, fortification of mucosal barrier, the homeostasis of the immune system, and protection against invasion of pathogenic microorganisms. Microbiota ferments non-digestible dietary residues producing short-chain fatty acids (SCFAs, such as n-butyrate, acetate, and propionate) which modulate the host energy balance increasing the nutrients availability (Samuel et al., 2008). Fermented SCFAs, secreted into the gut lumen, exceed the epithelial barrier and are released into the bloodstream. In this way they reach different organs and are used as substrates for energy metabolism. Hepatocyte cells, in particular, use propionate for gluconeogenesis. SCFAs are involved in the gut-brain axis, stimulating the release of peptide YY (PYY) and 5-hydroxytryptamine (5-HT). They act as signaling molecules to regulate immune and inflammatory responses (Evans, Morris \& Marchesi, 2013). N-butyrate regulates neutrophil function and migration, increases the expression of tight junction proteins in colon epithelia, reduces mucosal permeability and inhibits inflammatory cytokines (Nicholson et al., 2012). Beside producing SCFAs, bacterial species of the intestinal microbiota synthesize glycan, amino acids, and vitamins (K, B12, biotin, folate and thiamine), thus participating in the host metabolism (Flint, Scott, Louis \& Duncan, 2012).

The recognition of commensal bacteria by toll-like receptors (TLRs) is necessary to stimulate the epithelial cell proliferation, protecting the epithelial surface against gut injury (Akira \& Hemmi, 2003). Paneth cells, the secretory cells of the small intestine epithelium, perceive enteric bacteria through TLRs activation and trigger the expression of various antimicrobial factors. This prevents the penetration of pathogenic bacteria over the intestinal barrier (Vaishnava, Behrendt, Ismail, Eckmann \& Hooper, 2008). The microbiota is also related to the development of the gut associated lymphoid tissue (GALT), the host immune system stimulating IgA secretion and inhibiting colonization of the GIT by pathogens. Protective functions are performed also by the microbiota through competition with pathogens for nutrients and receptors and the production of antimicrobial molecules to avoid colonization by pathogens (Akira \& Hemmi, 2003). Through ligands from commensal bacteria (as lipopolysaccharide, LPS), the gut microbiota influences the mucosal immune system development and function (Rakoff-Nahoum, Paglino, Eslami-Varzaneh, Edberg \& Medzhitov, 2004). Furthermore, the innate immune system can also recognize potentially pathogenic microbes through TLRs identification of particular molecules called pathogen associated molecular patterns (PAMP). This leads to an increase in cytokine levels and T-cell activation which are necessary for appropriate immune response to pathogens (RakoffNahoum et al., 2004).

In the present review, we summarize different experimental evidences about the potential mechanisms by which the physical activity might influence the gut microbiota. Besides, we discuss the health benefits of exercise and microbiota diversity. 
Mihaela JURDANA, Darja BARLIČ-MAGANJA: PHYSICAL ACTIVITY REGULATES THE INTESTINAL MICROBIOTA COMPOSITION, 99-114

\section{METHODS}

Electronic databases MEDLINE, Science direct and PubMed including the original science articles and reviews, mainly published in the last two years were used to search the literature. Based on the keywords: microbiota, moderate exercise, intensive exercise, gut and health; the role of exercise on microbial composition and benefits to health were described. The search was not restricted to the type of study (i.e., species, metaanalysis, case-control, prospective cohort studies, reviews), sample size, year of publication, publication status or follow-up; however, we only included articles published in English and did not take into account other publications (i.e. conference presentations, abstracts, seminars, doctorate thesis).

\section{RESULTS}

\section{Microbiota and Diseases}

Physiological gut microbiota variations have huge implications on human health. Alteration of gut microbiota composition, often defined as dysbiosis, is a cause or a consequence of different acute and chronic diseases not limited only to the GIT (Marchesi et al., 2016; Schmidt, Raes \& Bork, 2018). Dysbiosis is characterized by reduced bacterial biodiversity, loss of commensals with beneficial metabolic activities and overgrowth of pathogen bacteria (Kriss, Hazleton, Nusbacher, Martin \& Lozupone, 2018). This implies a disruption of the mutual equilibrium between gut bacteria and human physiology resulting in the increased intestinal permeability allowing bacteria or bacterial toxins and metabolites to enter into the host circulation and promote subclinical inflammation (Levy, Kolodziejczyk, Thaiss \& Elinav, 2017). Dysbiosis reduces the microbial metabolism and the formation of nutrients that the body needs for its proper functioning. Recent studies have linked gut microbiota with different gastrointestinal disorders like inflammatory bowel disease, ulcerative colitis, Crohn's disease and irritable bowel syndrome (Dieterich, Schink \& Zopf, 2018), as well as with metabolic diseases like obesity, diabetes, cardiovascular diseases (Arora \& Bäckhed, 2016) and cancer (Garrett, 2015). Alterations in microbiota composition are associated with the onset of autoimmune and allergic diseases including multiple sclerosis, rheumatoid arthritis, systemic lupus erythematosus, psoriasis, atopic dermatitis and food allergies (Tanaka \& Nakayama, 2017; McKenzie, Tan, Macia \& Mackay, 2017). Gut microbiota dysbiosis may be involved in the pathophysiology of neuropsychiatric disorders (depression, schizophrenia, autism spectrum disorder, dementia, Alzheimer's and Parkinson's disease (Ghaisas, Maher \& Kanthasamy, 2016; Kim \& Shin, 2018), kidney diseases (Knauf, Brewer \& Flavell, 2019), osteoporosis (Ohlsson \& Sjogren, 2015) and liver cirrhosis (Qin et al., 2014). 
Mihaela JURDANA, Darja BARLIČ-MAGANJA: PHYSICAL ACTIVITY REGULATES THE INTESTINAL MICROBIOTA COMPOSITION, 99-114

\section{Microbiota gut-brain-axis communication mechanism The role of aerobic exercise}

A sedentary lifestyle is associated with a greater incidence of many diseases: cardiovascular, type 2 diabetes, cancer, obesity, and metabolic syndrome. Recently, it has been demonstrated that exercise-induced beneficial modification of the gut microbiota composition is involved in modulation of disease states and modifies host physiology (Choi et al., 2013).

An imbalance diet with high saturated fats, sugar intake, and low fiber consumption in combination with physical inactivity can influence the composition of the microbiota (Proctor, Thiennimitr, Chattipakorn \& Chattipakorn, 2017). Poor dietary habits can induce gastrointestinal dysfunction and lead to inflammatory state (Dalton, Mermier \& Zuhl, 2019). It has been recently demonstrated that probiotic supplementation improves GI function, many symptoms of inflammatory diseases and psychological and cognition disorders (Dalton et al., 2019).

Regular aerobic physical activity can reduce the risk of several diseases and health conditions and improve the quality of life (Colcombe et al., 2006). Recently, human and animal studies have shown that aerobic exercise increases microbiota diversity altering the bacterial composition and influencing the important metabolites production of gut bacteria, like SCFAs, release and modulation of mucosal neurotransmitters and a brain-derived neurotrophic factor, also known as BDNF (Welly et al., 2016). In this way, aerobic exercise can affect the conditions associated with metabolic diseases, neural and behavioral disorders.

Many evidences suggested an important influence and communication between human gut microbiota and the brain in a bidirectional manner. The brain affects gut microbiota through the autonomic nervous system (the vagus nerve), while gut microbiota influences the brain through neuroendocrine signaling via hypothalamic-pituitary-adrenal axis (HPAA) and neurotransmitter serotonin (5-HT) regulation (Grenham, Clarke, Cryan, \& Dinan, 2011; Cryan \& Dinan, 2012; Forsythe, Kunze, \& Bienenstock, 2016; Dalton et al., 2019).

Disorders in the gut-brain axis functioning are discussed in the pathogenesis of different pathological states (metabolic and inflammatory diseases, psychiatric and depressive disorders, and neurological disorders) (Dieterich et al., 2018).

Vagus nerve activity allows communication between microbiota and brain because it connects the CNS (central nervous system) to ENS (enteric nervous system) and transfers the information from the ENS to CNS that leads to response based on the received information (Forsythe, Kunze, \& Bienenstock, 2012). The gut microbiota imbalance can induce CNS inflammatory response. It was demonstrated that a decreased vagus nerve activity is associated with irritable bowel syndrome IBS and many other intestinal inflammations, and depression. This communication is influenced by microbiota metabolites because it has been shown that probiotic supplementation of Bifidobacterium longum can modify the functional status of the vagus activity in the gut. (Bercik et al., 2011). 
Mihaela JURDANA, Darja BARLIČ-MAGANJA: PHYSICAL ACTIVITY REGULATES THE INTESTINAL MICROBIOTA COMPOSITION, 99-114

HPA hypothalamic-pituitary-axis regulates physical and mental stressors response and it is influenced by microbiota via a complex of neural immunoregulatory mechanism (Tsigos \& Chrousos, 2002). HPA axis is activated by vagus nerve or by metabolites such as LPS from the mucosal layer that promotes the release of inflammatory cytokines that exaggerate HPA activation (Grenham et al., 2011). HPA axis hyperresponsiveness and disturbances in microbiota have been associated with IBS and psychological disorders (Farzi, Fröhlich, \& Holzer, 2018).

BDNF acts on neurons of the central nervous system and the peripheral nervous system, promotes the survival of existing neurons, and encourages the growth and differentiation of new neurons and synapses. Recently, it has been shown to be an important regulator of gastrointestinal protein expression and regulation (Dokladny, Zuhl, $\&$ Moseley 2015). The probiotic supplements of Bifidobacterium improved the HPA response and restored the BDNF levels in rodents (Sudo et al., 2004).

Serotonin (5-HT) is an important neurotransmitter and hormone, it appears to play a key role in maintaining mood and cognition balance, intestinal secretion and motility, and is known as a key signaling molecule in the microbiota-gut-brain axis (O'Mahony, Clarke, Borre, Dinan \& Cryan 2015; Jenkins, Nguyen, Polglaze \& Bertrand, 2016). Germ free animals' studies demonstrated that microbiota plays a role in serotonin regulation and influences brain and gut function (Clarke et al., 2013; Yano et al., 2015). Other studies showed that Bacteroides fragilis supplementation improved control of tryptophan metabolism, the precursor of 5-TH, synthesis and improved GI function (Hsiao et al., 2013).

\section{Exercise and Gut Microbiota}

Regular moderate exercise can beneficially affect our body; it can reduce the metabolic and inflammatory disease in both humans and animals. The association between exercise training and alteration in immunity, metabolism and behavior has already been confirmed (Walsh et al., 2011).

\section{Animal Studies}

In animals, different forms of exercise, in particular, voluntary and forced, induced different effects on microbiome composition. Many studies with germ-free animals have indicated the relationship between gut microbiota and host function (Choi et al., 2013; Allen et al., 2018). Changes in gut microbiota and its metabolites can affect the structure of the mucus layer and immune system after gut microbiota colonization in germ-free animals. In the study of Allen et al. (2018) it was demonstrated that exercise training induced changes in the gut microbiota community structure of donor mice and caused changes of colon physiology in recipient mice after five weeks of gut microbiota transplant and colonization. Therefore, the gut microbiota composition of recipient mice is dependent of the physical activity level of their respective donor. This indicates that ex- 
Mihaela JURDANA, Darja BARLIČ-MAGANJA: PHYSICAL ACTIVITY REGULATES THE INTESTINAL MICROBIOTA COMPOSITION, 99-114

ercise training directly alters the host response by cytokines and gut metabolite production. SCFAs that have been shown to be up regulated after exercise training contribute to enhanced energy harvest and reduce gut inflammation in physically active host (Turnbaugh et al., 2006). The mechanism of this process still needs to be elucidated.

Other studies on animals provided evidence that voluntary exercise training increased the level of host butyrate concentrations and butyrate-producing bacterial genera associated with enhanced early life lean mass (Mika et al., 2015). Since butyrate protects against colon cancer and inflammatory diseases (Monda et al., 2017), it has been proposed that butyrate increase is associated with the colon cancer decrease by exercise (Matsumoto et al., 2008). The mechanism of gut microbiota changes with host increase in SCFAs and butyrate and host decrease in colon inflammation in response to exercise is not fully understood. These data underline the need for future investigation. Although it is certain that voluntary and/or forced exercise altered the gut microbiota composition in animals. It was confirmed that maternal gut microbiota during pregnancy and lactation had effects on offspring gut microbiota in rats. Exercise during pregnancy limited the unfavorable impacts of maternal obesity in offspring, affecting the plasma insulin and glucose concentration (Bhagavata Srinivasan, Raipuria, Bahari, Kaakoush, \& Morris, 2018). Others observed that when the exercise started in the juvenile period it modified different bacteria ratio with an increase of Bacteroidetes and a decrease in Firmicutes. Furthermore, juveniles exercise causes a major change in genera and lead to an increase in lean body mass, suggesting that early life exercise can influence the gut microbiota composition and may favor optimal development of brain function (Mika et al., 2015).

Many authors provide evidence that a routine physical activity is anti-inflammatory and protective against developing the chronic inflammatory disease (Cook et al., 2016).

\section{Human Studies}

To date, few studies on humans have indicated a positive influence of exercise on gut microbiota and confirmed the findings of the animal studies.

It has been shown that low-intensity exercise provides a positive effect on the gut by reducing transient stool time and contact time between pathogens and gastrointestinal mucosa layer (Petersen et al., 2017). In this manner, exercise prevents the risk of many diseases such as cancer and other inflammatory diseases. Other possible positive effects of exercise can include an elevated SCFAs and immunoglobulin production, decrease in LPS production and increase in butyrate concentration. The increase of fecal butyrate has anti-carcinogenic and anti-inflammatory properties (Petersen et al., 2017). Exercise-induced changes of microbiota diversity can contribute to reducing obesity and obesity-related complication.

In humans, a major study conducted on 86 elite rugby athletes compared to high and low BMI controls, showed a greater gut microbiota richness/diversity in rugby players (Clark et al., 2014). The increased microbial diversity was positively correlated with 
Mihaela JURDANA, Darja BARLIČ-MAGANJA: PHYSICAL ACTIVITY REGULATES THE INTESTINAL MICROBIOTA COMPOSITION, 99-114

protein consumption and creatinine kinase levels, suggesting that both, diet and exercise are drivers of biodiversity in the gut.

In addition, cardiorespiratory fitness (CRF), an indicator of physical fitness has been positively correlated with microbial diversity in 39 healthy individuals, especially in taxa that augmented the production of butyrate, a gut health indicator (Estaki et al., 2016). The authors of this study recommended that exercise could be prescribed in combating dysbiosis-associated diseases.

In the pilot study by Peterson et al. (2017), the microbiota of 22 professional and 11 amateur competitive cyclists was studied. They demonstrated that gut microbiota profiles of professional cyclists differed from amateur control and found a correlation between certain microorganisms in professional cyclists and high exercise load. This study indicates that exercise load alters the bacterial community structure.

Although the human study in this field is still scarce, previous animals and humans study showed the effects of exercise on microbiota regardless of diet. Murtaza and collaborators examined the effects of different dietary programs during intensified training on stool microbiota of elite endurance athletes (race walkers). This study revealed that dietary patterns exert an impact on gut microbiota profiles. In particular, a ketogenic low carbohydrate, high-fat diet was found to induce alterations in abundances of some bacteria species (Murtaza et al., 2019). Other longitudinal studies are needed to examine the effect of diets and gut microbiome on athlete training and performance.

The health benefits of physical activity in older adults have been established in more scientific studies. Recently, data demonstrated the association between physical exercise and gut microbiota diversity in the elderly (Jackson et al., 2016). Authors of many studies reported that gut microbiota composition is less different in some conditions, such as in hypertensive patients and in patients with obesity-associated inflammation and gastrointestinal diseases (Monda et al., 2017; Taniguchi et al., 2018). Exercise can modulate the gut microbiota diversity and could have positive effects on the pathogenesis of mentioned conditions. Since lower inflammation was shown in athletes, it is possible that exercise in older adults could decrease inflammatory markers. Exercise determined changes in microbial composition were correlated with the duration of physical activity. It was recently confirmed that short-term endurance exercise has little effect on gut microbiota composition and diversity in elderly men, but mentioned little changes in the microbiota which were associated with lower cardiometabolic risk factors (Taniguchi et al., 2018). The study suggests that the gut microbiota is influenced by high-intensity interval training and diet and might play a crucial role in modulating CV disease development (Juneau, Hayami, Gayda, Lacroix \& Nigam 2014).

Interestingly, a study by Tan et al. (2013) revealed that diet and exercise improved sleep quality and changes in gut microbiota composition in subjects with obesity-related disorders.

All these data highlight the need for future investigation in humans to elucidate how the moderate and rigorous physical activity induces changes in microbiota diversity, composition and function having beneficial effects on human health. 
Mihaela JURDANA, Darja BARLIČ-MAGANJA: PHYSICAL ACTIVITY REGULATES THE INTESTINAL MICROBIOTA COMPOSITION, 99-114

Table 1 summarizes articles that have investigated the role of exercise on gut microbiome in humans.

Table 1: Association between exercise and gut microbiota.

\begin{tabular}{|l|l|l|l|}
\hline Authors & Subjects & $\begin{array}{l}\text { Type of } \\
\text { exercise }\end{array}$ & Results \\
\hline Clark et al., 2014 & $\begin{array}{l}\text { Elite athletes and } \\
\text { controls }\end{array}$ & Rugby & $\begin{array}{l}\text { Bacterial diversity was } \\
\text { higher in athletes than in } \\
\text { control. }\end{array}$ \\
\hline Estaki et al., 2016 & $\begin{array}{l}\text { Healthy participants } \\
\text { with similar age and } \\
\text { BMI }\end{array}$ & Cardio & Butyrate production \\
\hline Petersen et al., 2017 & $\begin{array}{l}\text { Professional and } \\
\text { amateur cyclists }\end{array}$ & Cycling & $\begin{array}{l}\text { Exercise load influence } \\
\text { the bacterial community }\end{array}$ \\
\hline $\begin{array}{l}\text { Taniguchi et al., } \\
\mathbf{2 0 1 8}\end{array}$ & Patients & $\begin{array}{l}\text { Moderate/ } \\
\text { vigorous }\end{array}$ & Decrease inflammation \\
\hline
\end{tabular}

\section{CONCLUSION}

The existing study data indicate that exercise can induce alterations in gut microbiota composition with beneficial effects for the host. Exercise improves microbiota diversity, maintenance of normal gut physiology and contributes to reducing inflammatory markers in different pathological states. Furthermore, exercise stimulates the production of metabolites such as butyrate and SCFAs, protecting us against GI disorders and colon cancer. This may explain why exercise can be a therapeutic strategy during treatment for many disorders in particular psychological and GI diseases. Nevertheless, further studies are needed to understand the mechanisms responsible for these effects. Further exploration is required to understand how physical activity and diet independently influence health. In the future, exercise prescription may hopefully contribute to our health status through the modification of gut microbiota. 
Mihaela JURDANA, Darja BARLIČ-MAGANJA: PHYSICAL ACTIVITY REGULATES THE INTESTINAL MICROBIOTA COMPOSITION, 99-114

\section{REFERENCES}

Aagaard, K., Ma, J., Antony, K. M., Ganu, R., Petrosino, J., \& Versalovic, J. (2014). The placenta harbors a unique microbiome. Science Translational Medicine, 6(237), 237ra65. https://doi.org/10.1126/scitranslmed.3008599.

Akira, S., \& Hemmi, H. (2003). Recognition of pathogen-associated molecular patterns by TLR family. Immunology Letters, 85(2), 85-95. https://doi.org/10.1016/S01652478(02)00228-6.

Arora, T., \& Bäckhed, F. (2016). The gut microbiota and metabolic disease: current understanding and future perspectives. Journal of Internal Medicine, 280(4), 339-349. https://doi.org/10.1111/joim.12508.

Allen, J. M., Mailing, L. J., Cohrs, J., Salmonson, C., Fryer, J. D., Nehra, V., ... Woods, J. A. (2018). Exercise training-induced modification of the gut microbiota persists after microbiota colonization and attenuates the response to chemically-induced colitis in gnotobiotic mice. Gut Microbes, 9(2), 115-130. https://doi.org/10.1080/19490976.20 17.1372077 .

Bäckhed, F., Ley, R. E., Sonnenburg, J. L., Peterson, D. A., \& Gordon, J. I. (2005). Host-bacterial mutualism in the human intestine. Science, 307(5717), 1915-1920. https://doi.org/10.1126/science.1104816.

Bercik, P., Park, A. J., Sinclair, D., Khoshdel, A., Lu, J., Huang, X., ... Verdu, E. F. (2011). The anxiolytic effect of Bifidobacterium longum NCC3001 involves vagal pathways for gut-brain communication. Neurogastroenterology and motility: the official journal of the European Gastrointestinal Motility Society, 23(12), 1132-1139. https:// doi.org/10.1111/j.1365-2982.2011.01796.x.

Bhagavata Srinivasan, S. P., Raipuria, M., Bahari, H., Kaakoush, N. O., \& Morris, M. J. (2018). Impacts of diet and exercise on maternal gut microbiota are transferred to offspring. Frontiers in Endocrinology, 9, 716. https://doi.org/10.3389/fendo.2018.00716

Bokulich, N. A., Chung, J., Battaglia, T., Henderson, N., Jay, M., Li, H., ... Blaser, M. J. (2016). Antibiotics, birth mode, and diet shape microbiome maturation during early life. Science Translational Medicine, 8(343), 343ra82. https://doi.org/10.1126/scitranslmed. $\operatorname{aad} 7121$.

Choi, J. J., Eum, S. Y., Rampersaud, E., Daunert, S., Abreu, M. T., \& Toborek, M. (2013). Exercise attenuates PCB-induced changes in the mouse gut microbiome. Environmental Health Perspectives, 121(6), 725-730. https://doi.org/10.1289/ehp.1306534.

Claesson, M. J., Jeffery, I. B., Conde, S., Power, S. E., O‘Connor, E. M., Cusack, S., ... O'Toole, P. W. (2012). Gut microbiota composition correlates with diet and health in the elderly. Nature, 488(7410), 178-184. https://doi.org/10.1038/nature11319.

Clarke, G., Grenham, S., Scully, P., Fitzgerald, P., Moloney, R., Shanahan, F., ...Cryan, J. F. (2013). The microbiome-gut-brain axis during early life regulates the hippocampal serotonergic system in a sex-dependent manner. Molecular Psychiatry, 18(6), 666-673. https://doi.org/10.1038/mp.2012.77.

Clarke, S. F., Murphy, E. F., O’Sullivan, O., Lucey, A. J., Humphreys, M., Hogan, A., ... Cotter, P. D. (2014). Exercise and associated dietary extremes impact on gut microbial diversity. Gut, 63(12), 1913-1920. https://doi.org/10.1136/gutjnl-2013-306541. 
Mihaela JURDANA, Darja BARLIČ-MAGANJA: PHYSICAL ACTIVITY REGULATES THE INTESTINAL MICROBIOTA COMPOSITION, 99-114

Clemente, J. C., Ursell, L. K., Parfrey, L. W., \& Knight, R. (2012). The impact of the gut microbiota on human health: an integrative view. Cell, 148(6), 1258-1270. https://doi. org/10.1016/j.cell.2012.01.035.

Colcombe, S. J., Erickson, K. I., Scalf, P. E., Kim, J. S., Prakash, R., McAuley, E., ... Kramer, A. F. (2006). Aerobic exercise training increases brain volume in aging humans. The Journals of Gerontology. Series A, Biological Sciences and Medical Sciences, 61(11), 1166-1170. https://doi.org/10.1093/gerona/61.11.1166.

Cook, M. D., Allen, J. M., Pence, B. D., Wallig, M. A., Gaskins, H. R., White, B. A., \& Woods, J. A. (2016). Exercise and gut immune function: evidence of alterations in colon immune cell homeostasis and microbiome characteristics with exercise training. Immunology and Cell Biology, 94(2), 158-163. https://doi.org/10.1038/icb.2015.108

Cryan, J. F., \& Dinan, T. G. (2012). Mind-altering microorganisms: the impact of the gut microbiota on brain and behaviour. Nature Reviews Neuroscience, 13(10), 701-712. https://doi.org/10.1038/nrn3346.

Dalton, A., Mermier, C., \& Zuhl, M. (2019). Exercise influence on the microbiome-gutbrain axis. Gut Microbes, 10(5), 555-568. https://doi.org/10.1080/19490976.2018.156 2268.

Dieterich, W., Schink, M., \& Zopf, Y. (2018). Microbiota in the gastrointestinal tract. Medical Sciences (Basel, Switzerland), 6(4), 116. https://doi.org/10.3390/medsci6040116.

Dokladny, K., Zuhl, M. N., \& Moseley, P. L. (2015). Intestinal epithelial barrier function and tight junction proteins with heat and exercise. Journal of Applied Physiology, 120(6), 692-701. https://doi.org/10.1152/japplphysiol.00536.2015.

Eckburg, P. B., Bik, E. M., Bernstein, C. N., Purdom, E., Dethlefsen, L., Sargent M., ... Relman, D. A. (2005). Diversity of the human intestinal microbial flora. Science, 308(5728), 1635-1638. https://doi.org/10.1126/science.1110591.

Estaki, M., Pither, J., Baumeister, P., Little, J. P., Gill, S. K., Ghosh, S., ... Gibson, D. L. (2016). Cardiorespiratory fitness as a predictor of intestinal microbial diversity and distinct metagenomic functions. Microbiome, 4(1), 42. https://doi.org/10.1186/s40168016-0189-7.

Evans, J. M., Morris, L. S., \& Marchesi, J. R. (2013). The gut microbiome: the role of a virtual organ in the endocrinology of the host. Journal of Endocrinology, 218(3), R37R47. https://doi.org/10.1530/joe-13-0131.

Farzi, A., Fröhlich, E. E., \& Holzer, P. (2018). Gut microbiota and the neuroendocrine system. Neurotherapeutics: the Journal of the American Society for Experimental NeuroTherapeutics, 15(1), 5-22. https://doi.org/10.1007/s13311-017-0600-5.

Flint, H. J., Scott, K. P., Louis, P., \& Duncan, S. H. (2012). The role of the gut microbiota in nutrition and health. Nature Reviews Gastroenterology \& Hepatology, 9(10), 577-589. https://doi.org/10.1038/nrgastro.2012.156.

Forsythe, P., Kunze, W. A., \& Bienenstock, J. (2012). On communication between gut microbes and the brain. Current Opinion in Gastroenterology, 28(6), 557-562. https:// doi.org/10.1097/MOG.0b013e3283572ffa.

Forsythe, P., Kunze, W., \& Bienenstock, J. (2016). Moody microbes or fecal phrenology: what do we know about the microbiota-gut-brain axis? BMC Medicine, 14, 58. https:// doi.org/10.1186/s12916-016-0604-8.

Garrett, W. S. (2015). Cancer and the microbiota. Science, 348(6230), 80-86. https://doi. org/10.1126/science.aaa4972. 
Mihaela JURDANA, Darja BARLIČ-MAGANJA: PHYSICAL ACTIVITY REGULATES THE INTESTINAL MICROBIOTA COMPOSITION, 99-114

Ghaisas, S., Maher, J., \& Kanthasamy, A. (2016). Gut microbiome in health and disease: linking the microbiome-gut-brain axis and environmental factors in the pathogenesis of systemic and neurodegenerative diseases. Pharmacology \& Therapeutics, 158, 52-62. https://doi.org/10.1016/j.pharmthera.2015.11.012.

Grenham, S., Clarke, G., Cryan, J. F., \& Dinan, T. G. (2011). Brain-gut-microbe communication in health and disease. Frontiers in Physiology, 2, 94. https://doi.org/10.3389/ fphys.2011.00094.

Hsiao, E. Y., McBride, S. W., Hsien, S., Sharon, G., Hyde, E. R., McCue, T., ... Mazmanian, S. K. (2013). Microbiota modulate behavioral and physiological abnormalities associated with neurodevelopmental disorders. Cell, 155(7), 1451-1463. https://doi. org/10.1016/j.cell.2013.11.024.

Jackson, M. A., Jeffery, I. B., Beaumont, M., Bell J. T., Clark, A. G., Ley, R. E., ... Steves, C. J. (2016). Signatures of early frailty in the gut microbiota. Genome Medicine, 8(1), 8. https://doi.org/10.1186/s13073-016-0262-7.

Jenkins, T. A., Nguyen, J. C., Polglaze, K. E., \& Bertrand, P. P. (2016). Influence of tryptophan and serotonin on mood and cognition with a possible role of the gut-brain axis. Nutrients, 8(1), 56. https://doi.org/10.3390/nu8010056.

Juneau, M., Hayami, D., Gayda, M., Lacroix, S., \& Nigam, A. (2014). Provocative issues in heart disease prevention. Canadian Journal of Cardiology, 30(12 Suppl), S401-409. https://doi.org/10.1016/j.cjca.2014.09.014.

Kashtanova, D. A., Popenko, A. S., Tkacheva, O. N., Tyakht, A. B., Alexeev, D. G., \& Boytsov, S. A. (2016). Association between the gut microbiota and diet: fetal life, early childhood, and further life. Nutrition, 32(6), 620-627. https://doi.org/10.1016/j. nut.2015.12.037.

Kim, Y. K., \& Shin, C. (2018). The microbiota-gut-brain axis in neuropsychiatric disorders: pathophysiological mechanisms and novel treatments. Current Neuropharmacology, 16(5), 559-573. https://doi.org/10.2174/1570159X15666170915141036.

Knauf, F., Brewer, J. R., \& Flavell, R. A. (2019). Immunity, microbiota and kidney disease. Nature Reviews Nephrology, 15, 263-274. https://doi.org/10.1038/s41581-0190118-7.

Kriss, M., Hazleton, K. Z., Nusbacher, N. M., Martin, C. G., \& Lozupone, C. A. (2018). Low diversity gut microbiota dysbiosis: drivers, functional implications and recovery. Current Opinion in Microbiology, 44, 34-40. https://doi.org/10.1016/j.mib.2018.07.003.

Levy, M., Kolodziejezyk, A. A., Thaiss, C. A., \& Elinav, E. (2017). Dysbiosis and the immune system. Nature Reviews Immunology, 17(4), 219-232. https://doi.org/10.1038/ nri.2017.7.

Marchesi, J. R., Adams, D. H., Fava, F., Hermes, G. D., Hirschfield, G. M., Hold, G., ... Hart, A. (2016). The gut microbiota and host health: a new clinical frontier. Gut, 65(2), 330-339. https://doi.org/10.1136/gutjnl-2015-309990.

Matsumoto, M., Inoue, R., Tsukahara, T., Ushida, K., Chiji, H., Matsubara, N., \& Hara, H. (2008). Voluntary running exercise alters microbiota composition and increases n-butyrate concentration in the rat cecum. Bioscience, Biotechnology and Biochemistry, 72(2), 572-576. https://doi.org/10.1271/bbb.70474.

McKenzie, C., Tan, J., Macia, L., \& Mackay, C. R. (2017). The nutrition-gut microbiome-physiology axis and allergic diseases. Immunology Reviews, 278(1), 277-295. https://doi.org/10.1111/imr.12556. 
Mihaela JURDANA, Darja BARLIČ-MAGANJA: PHYSICAL ACTIVITY REGULATES THE INTESTINAL MICROBIOTA COMPOSITION, 99-114

Mika, A., Van Treuren, W., González, A., Herrera, J. J., Knight, R., \& Fleshner, M. (2015). Exercise is more effective at altering gut microbial composition and producing stable changes in lean mass in juvenile versus adult male F344 rats. PloS one, 10(5), e0125889. https://doi.org/10.1371/journal.pone.0125889.

Milani, C., Duranti, S., Bottacini, F., Casey, E., Turroni, F., Mahony, J., ... Ventura, M. (2017). The first microbial colonizers of the human gut: composition, activities, and health implications of the infant gut microbiota. Microbiology and Molecular Biology Reviews, 81(4), e00036-17. https://doi.org/10.1128/MMBR.00036-17.

Milani, C., Ferrario, C., Turroni, F., Duranti, S., Mangifesta, M., van Sinderen, D., \& Ventura, M. (2016). The human gut microbiota and its interactive connections to diet. Journal of Human Nutrition and Dietetics, 29(5), 539-546. https://doi.org/10.1111/ jhn. 12371.

Monda, V., Villano, I., Messina, A., Valenzano, A., Esposito, T., Moscatelli, F., ... Messina, G. (2017). Exercise modifies the gut microbiota with positive health effects. Oxidative Medicine and Cellular Longevity, 2017, 3831972. https://doi. org/10.1155/2017/3831972.

Murtaza, N., Burke, L. M., Vlahovich, N., Charlesson, B., O’ Neill, H., Ross, M. L., ... Morrison, M. (2019). The effects of dietary pattern during intensified training on stool microbiota of elite race walkers. Nutrients, 11(2), 261. https://doi.org/10.3390/ nu11020261.

Nicholson, J. K., Holmes, E., Kinross, J., Burcelin, R., Gibson, G., Jia, W., \& Pettersson, S. (2012). Host-gut microbiota metabolic interactions. Science, 336(6086), 1262 1267. https://doi.org/10.1126/science.1223813.

O'Hara, A. M., \& Shanahan, F. (2006). The gut flora as a forgotten organ. EMBO Reports, 7(7), 688-693. https://doi.org/10.1038/sj.embor.7400731.

Ohlsson, C., \& Sjögren, K. (2015). Effects of the gut microbiota on bone mass. Trends in Microbiology, 26(2), 69-74. https://doi.org/10.1016/j.tem.2014.11.004.

O'Mahony, S., Clarke, G., Borre, Y., Dinan, T. \& Cryan, J. (2015). Serotonin, tryptophan metabolism and the brain-gut-microbiome axis. Behavioural Brain Research, 277, 32-48. https://doi.org/10.1016/j.bbr.2014.07.027.

Petersen, L. M., Bautista, E. J., Nguyen, H., Hanson, B. M., Chen, L., Lek, S. H., ... Weinstock, G. M. (2017). Community characteristics of the gut microbiomes of competitive cyclists. Microbiome, 5(1), 98. https://doi.org/10.1186/s40168-017-0320-4.

Proctor, C., Thiennimitr, P., Chattipakorn, N., \& Chattipakorn, S. C. (2017). Diet, gut microbiota and cognition. Metabolic Brain Disease, 32(1), 1-17. https://doi.org/10.1007/ s11011-016-9917-8.

Qin, N., Yang, F., Li, A., Prifti, E., Chen, Y., Shao, L., ... Li, L. (2014). Alterations of the human gut microbiome in liver cirrhosis. Nature, 513(7516), 59-64. https://doi. org/10.1038/nature13568.

Rakoff-Nahoum, S., Paglino, J., Eslami-Varzaneh, F., Edberg, S., \& Medzhitov, R. (2004). Recognition of commensal microflora by toll-like receptors is required for intestinal homeostasis. Cell, 118(2), 229-241. https://doi.org/10.1016/j.cell.2004.07.002.

Rodriguez, J. M., Murphy, K., Stanton, C., Ross, R. P., Kober, O. I., Juge, N., Collado, M. C. (2015). The composition of the gut microbiota throughout life, with an emphasis on early life. Microbial Ecology in Health and Disease, 26(2), 26050, https:// doi.org/10.3402/mehd.v26.26050. 
Mihaela JURDANA, Darja BARLIČ-MAGANJA: PHYSICAL ACTIVITY REGULATES THE INTESTINAL MICROBIOTA COMPOSITION, 99-114

Samuel, B. S., Shaito, A., Motoike, T., Rey, F. E., Backhed, F., Manchester, J. K., ... Gordon, J. I. (2008). Effects of the gut microbiota on host adiposity are modulated by the short-chain fatty-acid binding G protein-coupled receptor, Gpr41. Proceedings of the National Academy of Sciences of the United States of America, 105(43), 16767-16772. https://doi.org/10.1073/pnas.0808567105.

Schmidt, T. S. B., Raes, J., \& Bork, P. (2018). The human gut microbiome: from association to modulation. Cell, 172(6), 1198-1215. https://doi.org/10.1016/j.cell.2018.02.044.

Sudo, N., Chida, Y., Aiba, Y., Sonoda, J., Oyama, N., Yu, X. N., ... Koga, Y. (2004). Postnatal microbial colonization programs the hypothalamic-pituitary-adrenal system for stress response in mice. The Journal of Physiology, 558(1), 263-275. https://doi. org/10.1113/jphysiol.2004.063388.

Tan, X., Saarinen, A., Mikkola, T. M., Tenhunen, J., Martinmäki, S., Rahikainen, A., ... Cheng, S. (2013). Effects of exercise and diet interventions on obesity-related sleep disorders in men: study protocol for a randomized controlled trial. Trials, 14, 235. https://doi.org/10.1186/1745-6215-14-235.

Tanaka, M., \& Nakayama, J. (2017). Development of the gut microbiota in infancy and its impact on health in later life. Allergology International, 66(4), 515-522. https://doi. org/10.1016/j.alit.2017.07.010.

Taniguchi, H., Tanisawa, K., Sun, X., Kubo, T., Hoshino, Y., Hosokawa, ... Higuchi, M. (2018). Effects of short-term endurance exercise on gut microbiota in elderly men. Physiological Reports, 6(23), e13935. https://doi.org/10.14814/phy2.13935.

Ticinesi, A., Lauretani, F., Tana, C., Nouvenne, A., Ridolo, E., \& Meschi, T. (2019). Exercise and immune system as modulators of intestinal microbiome: implications for the gut-muscle axis hypothesis. Exercise Immunology Review, 25, 84-95. Retrieved from: http://eir-isei.de/2019/eir-2019-084-article.pdf.

Tsigos, C. \& Chrousos, G. P. (2002). Hypothalamic-pituitary-adrenal axis, neuroendocrine factors and stress. The Journal of Psychosomatic Research, 53(4), 865-871. https://doi. org/10.1016/S0022-3999(02)00429-4.

Turnbaugh, P. J., Ley, R. E., Mahowald, M. A., Magrini, V., Mardis, E. R., \& Gordon, J. I. (2006). An obesity-associated gut microbiome with increased capacity for energy harvest. Nature, 444(7122), 1027-1031. https://doi.org/10.1038/nature05414.

Vaishnava, S., Behrendt, C. L., Ismail, A. S., Eckmann, L., \& Hooper, L. V. (2008). Paneth cells directly sense gut commensals and maintain homeostasis at the intestinal host-microbial interface. Proceedings of the National Academy of Sciences, 105(52), 20858-20863. https://doi.org/10.1073/pnas.0808723105.

Walsh, N. P., Gleeson, M., Shephard, R. J., Gleeson, M., Woods, J. A., Bishop, N. C., ... Simon, P. (2011). Position statement. Part one: Immune function and exercise. Exercise Immunology Review, 17, 6-63. Retrieved from: http://eir-isei.de/2011/eir-2011-006-article.pdf.

Welly, R. J., Liu, T. W., Zidon, T. M., Rowles, J. L., Park, Y. M., Smith, T. N., ... VieiraPotter, V. (2016). Comparison of diet vs. exercise on metabolic function \& gut microbiota in obese rats. Medicine \& Science in Sports \& Exercise, 48(9), 1688-1698. https:// doi.org/10.1249/MSS.0000000000000964.

Yano, J. M., Yu, K., Donaldson, G. P., Shastri, G. G., Ann, P., Ma, L., ... Hsiao, E. Y. (2015). Indigenous bacteria from the gut microbiota regulate host serotonin biosynthesis. Cell, 161(2), 264-276. https://doi.org/10.1016/j.cell.2015.02.047. 
Mihaela JURDANA, Darja BARLIČ-MAGANJA: PHYSICAL ACTIVITY REGULATES THE INTESTINAL MICROBIOTA COMPOSITION, 99-114

Yatsunenko, T., Rey, F. E., Manary, M. J., Trehan, I., Dominguez-Bello, M. G., Contreras, M., ... Gordon, J. I. (2012). Human gut microbiome viewed across age and geography. Nature, 486(7402), 222-227. https://doi.org/10.1038/nature11053. 